\title{
Overnourishing pregnant adolescent ewes stimulates perirenal fat deposition in their growth restricted foetuses*
}

\author{
M. Matsuzaki ${ }^{1}$, J.S. Milne ${ }^{2}$, R.P. Aitken ${ }^{2}$, D.A. Redmer ${ }^{3}$ \\ and J.M. Wallace ${ }^{2,4}$ \\ ${ }^{I}$ Department of Animal and Grassland Research, \\ National Agricultural Research Center for Kyushu Okinawa Region, Kumamoto 861-1192, Japan \\ ${ }^{2}$ Development, Growth and Function Division, \\ Rowett Research Institute, Aberdeen AB21 9SB, UK \\ ${ }^{3}$ Department of Animal and Range Sciences, \\ North Dakota State University, Fargo ND 58105, USA
}

\begin{abstract}
The influence of maternal nutrition during pregnancy on foetal adipose tissue development was studied in a sheep model of foetal growth restriction, achieved by overnourishing adolescent ewes. At Day 130 of gestation, the growth restricted foetuses from the overnourished rapidly growing dams $(\mathrm{H})$ had higher perirenal fat proportions compared to control foetuses from the moderately fed adolescent dams (M). The mRNA expression for uncoupling protein (UCP)1 and leptin in foetal perirenal fat was equivalent between groups, but irrespective of maternal nutrition UCP1 was negatively correlated with foetal weight. Maternal plasma prolactin and glucose concentrations were higher in the $\mathrm{H}$ group and were positively associated with foetal perirenal fat deposition.
\end{abstract}

KEY WORDS: adolescent pregnancy, foetal fat deposition, foetal growth, nutrition, prolactin, uncoupling protein 1

\section{INTRODUCTION}

At birth, newborn sheep need to produce heat in order to prevent hypothermia. Non-shivering thermogenesis in brown adipose tissue is crucial for successful transition to extrauterine life. Functionality or maturation of foetal adipose tissue

\footnotetext{
"Masatoshi Matsuzaki was supported by a fellowship from the National Agriculture and Bio-oriented Research Organization for a one year stay at the Rowett Research Institute

${ }^{4}$ Corresponding author: e-mail: Jacqueline.Wallace@rowett.ac.uk
} 
is characterized by the appearance of the brown adipose tissue-specific uncoupling protein (UCP)1, which appears over the last half of gestation in the ovine foetus (Clarke et al., 1997). Prolactin and prolactin receptor appear to be associated with increased UCP1 abundance and with an improved ability of the neonate to thermoregulate (Pearce et al., 2003).

We have previously shown that overnourishing the growing adolescent sheep results in placental growth restriction and the premature delivery of low birth weight lambs (Wallace et al., 1996, 2001). The purpose of this study was to detail the relationship between foetal adipose development and endocrine/ metabolic status in similarly growth restricted foetuses.

\section{MATERIAL AND METHODS}

Singleton pregnancies were established in adolescent ewe lambs using embryo transfer and a single sire to minimize the heterogeneity of the offspring as described previously (Wallace et al., 1997). Immediately following embryo transfer, recipient ewes were allocated to one of two nutritional treatments; a high $(\mathrm{H})$ or moderate $(\mathrm{M})$ level of a complete diet (11 MJ ME and $140 \mathrm{~g} \mathrm{CP}$ per $\mathrm{kg}$ dry matter) to promote rapid or low maternal growth rates, respectively. The $\mathrm{M}$ level was designed as a control group in that this level of intake was predicted to optimize foetal growth in this genotype while the $\mathrm{H}$ level was equivalent to ad libitum intakes. On average these nutritional treatments result in a twofold difference in dietary intake between groups.

On day 130 of gestation (term $=145$ days), ewes and foetuses were killed by administration of an overdose of sodium pentobarbitone. Blood samples were collected and selected organs were weighed and sampled from both dams and foetuses. Plasma hormone and metabolite concentrations were determined. Messenger RNA levels for UCP1 and leptin in foetal perirenal adipose tissue were measured using quantitative real-time RT-PCR (Wallace et al., 2004).

The experiment was replicated in consecutive years and the numbers of ewes for each year were 8 and 6 for the M, and 6 and 6 for $\mathrm{H}$ groups, respectively. Data were analysed by ANOVA of GLM for the main effect of nutrition, replication of experiment in consecutive years and their interaction.

\section{RESULTS}

Overnourishing pregnant adolescent dams led to foetal growth restriction as evidenced by a $28 \%$ reduction $(\mathrm{P}<0.001)$ in foetal weight in the $\mathrm{H}$ compared with the M group (Table 1). Relative foetal perirenal fat weight was significantly increased in the growth restricted foetuses as was the relative weight of the foetal brain. In contrast the weight of the foetal liver was reduced in proportion to the 
decrease in foetal body weight resulting in a significantly higher brain:liver weight in $\mathrm{H}$ versus $\mathrm{M}$ groups. Maternal plasma concentrations of insulin, prolactin and glucose were elevated by the high plane of nutrition (Table 2). Conversely in the foetal circulation, prolactin concentrations were reduced $(\mathrm{P}<0.03)$ in the growth restricted compared with control foetuses.

Table 1. Foetal and selected organ weights at day 130 of gestation in the $\mathrm{M}$ and $\mathrm{H}$ groups

\begin{tabular}{|c|c|c|c|c|c|}
\hline \multirow{2}{*}{ Indices } & \multirow{2}{*}{ M } & \multirow{2}{*}{$\mathrm{H}$} & \multicolumn{3}{|c|}{ P-value } \\
\hline & & & nutrition & block $^{1}$ & nutrition $\times$ block \\
\hline Foetal weight, $g$ & $4595 \pm 134$ & $3317 \pm 265$ & $<0.001$ & 0.50 & 0.20 \\
\hline \multicolumn{6}{|c|}{ Absolute foetal organ weights, $g$} \\
\hline brain & $43.0 \pm 0.8$ & $40.2 \pm 1.2$ & 0.07 & 0.97 & 0.99 \\
\hline liver & $140.8 \pm 7.9$ & $102.8 \pm 10.7$ & 0.009 & 0.91 & 0.34 \\
\hline perirenal fat & $17.4 \pm 0.8$ & $15.7 \pm 1.1$ & 0.07 & 0.02 & 0.02 \\
\hline brain:liver, $\mathrm{g} / \mathrm{g}$ & $0.32 \pm 0.02$ & $0.44 \pm 0.05$ & 0.01 & 0.34 & 0.12 \\
\hline \multicolumn{6}{|c|}{ Relative foetal organ weights, $\mathrm{g} / \mathrm{kg} B W$} \\
\hline brain & $9.42 \pm 0.20$ & $13.01 \pm 1.06$ & 0.001 & 0.19 & 0.10 \\
\hline liver & $30.5 \pm 1.2$ & $30.4 \pm 1.2$ & 0.90 & 0.73 & 0.64 \\
\hline perirenal fat & $3.81 \pm 0.17$ & $4.88 \pm 0.30$ & 0.002 & 0.003 & 0.78 \\
\hline
\end{tabular}

${ }^{1}$ replication of experiment was considered as block

Table 2. Maternal and foetal plasma hormone and metabolite concentrations at day 130 of gestation in the $\mathrm{M}$ and $\mathrm{H}$ groups

\begin{tabular}{lccccc}
\hline \multirow{2}{*}{ Indices } & $\mathrm{M}$ & $\mathrm{H}$ & \multicolumn{3}{c}{ P-value } \\
\cline { 4 - 6 } & & & & & \\
\hline Maternal & & & & & \\
$\quad$ insulin, $\mu \mathrm{u} / \mathrm{ml}$ & $73.4 \pm 15.9$ & $154.6 \pm 26.9$ & 0.006 & 0.02 & 0.43 \\
$\quad$ rolactin, $\mathrm{ng} / \mathrm{ml}$ & $32.0 \pm 11.9$ & $112.8 \pm 24.5$ & 0.002 & 0.003 & 0.39 \\
$\quad$ glucose, $\mathrm{mg} / \mathrm{dl}$ & $60.0 \pm 3.4$ & $85.3 \pm 4.8$ & $<0.001$ & 0.72 & 0.87 \\
& & & & & \\
Foetal & & & & & \\
$\quad$ insulin, $\mu \mathrm{u} / \mathrm{ml}$ & $12.7 \pm 1.5$ & $8.9 \pm 1.6$ & 0.11 & 0.53 & 0.37 \\
$\quad$ prolactin, $\mathrm{ng} / \mathrm{ml}$ & $70.9 \pm 16.6$ & $43.5 \pm 13.1$ & 0.03 & $<0.001$ & 0.31 \\
$\quad$ NEFA, $\mu \mathrm{mol} / \mathrm{l}$ & $65.2 \pm 2.6$ & $71.3 \pm 6.4$ & 0.39 & 0.50 & 0.06 \\
\hline
\end{tabular}

${ }^{1}$ replication of experiment was considered as block

Table 3. Messenger RNA expression for UCP1 and leptin in foetal perirenal adipose tissue of the M and $\mathrm{H}$ groups at Day 130 of gestation ${ }^{1}$

\begin{tabular}{lccccc}
\hline \multirow{2}{*}{ Indices } & \multirow{2}{*}{$\mathrm{M}$} & $\mathrm{H}$ & \multicolumn{3}{c}{ P-value } \\
\cline { 4 - 6 } & & & nutrition & block $^{1}$ & nutrition $\times$ block \\
\hline UCP1 & $33.1 \pm 5.7$ & $53.2 \pm 9.5$ & 0.10 & 0.25 & 0.59 \\
Leptin & $26.7 \pm 3.8$ & $26.7 \pm 2.7$ & 0.73 & 0.02 & 0.09 \\
\hline
\end{tabular}

${ }^{1}$ expressed as ratio to $18 \mathrm{~S}$ ribosomal RNA for each sample, $\mathrm{X} 20^{-1}$

${ }^{2}$ replication of experiment was considered as block 
Foetal perirenal fat mRNA expression of UCP1 and leptin was not influenced by maternal nutrition. However, irrespective of treatment group, UCP1 mRNA expression was negatively correlated with foetal weight $(\mathrm{r}=-0.600 ; \mathrm{P}<0.01)$ while foetal plasma insulin was positively correlated with foetal fat leptin mRNA expression $(\mathrm{r}=0.600 ; \mathrm{P}<0.01)$. Correlation analyses also revealed that the relative foetal perirenal fat mass was positively associated with maternal plasma prolactin and glucose concentrations ( $\mathrm{r}=0.564$ and 0.571 , respectively; $\mathrm{P}<0.01$ ).

\section{DISCUSSION}

It is intriguing that the growth restricted foetuses from the overnourished adolescent dams exhibited enhanced adipose tissue development, at least with respect to mass. While the mechanistic basis of this observation has yet to be determined, it is possible that the increase in relative adiposity is due to higher foetal glucose availability earlier in gestation, prior to placental limitation of foetal glucose supply. Maternal glucose concentrations are elevated throughout gestation in overnourished dams (Wallace et al., 1997) and result in higher foetal glucose concentrations in early pregnancy (J.M. Wallace, unpublished). These elevated glucose concentrations may drive an increased pre-adipocyte pool in early pregnancy and thus increased potential for fat accumulation later in prenatal development. The negative correlation between UCP1 mRNA and foetal weight is intriguing and may indicate that UCP1 expression is up-regulated earlier in the growth restricted foetuses, which generally are spontaneously delivered 2-3 days before the normally growing controls (Wallace et al., 2001). The higher maternal prolactin in the overnourished dams may play a role in the increased foetal adiposity and the trend towards higher UCP1 expression. Further investigations of perirenal fat prolactin receptor activity and whole body composition are clearly warranted in this model system. The increase in relative adiposity in the main foetal internal fat depot may have implications for the programming of postnatal body composition and metabolic disease susceptibility.

\section{REFERENCES}

Clarke L., Heasman L., Firth K., Symonds M.E., 1997. Influence of route of delivery and ambient temperature on thermoregulation in newborn lambs. Amer. J. Physiol. 272, R1931-R1939

Pearce S., Mostyn A., Alves-Guerra M.C., Pecqueur C., Miroux B., Webb R., Stephenson T., Symonds M.E., 2003. Prolactin, prolactin receptor and uncoupling proteins during fetal and neonatal development. Proc. Nutr. Soc. 62, 421-427

Wallace J.M., Aitken R.P., Cheyne M.A., 1996. Nutrient partitioning and fetal growth in rapidly growing adolescent ewes. J. Reprod. Fertil. 107, 183-190

Wallace J.M., Bourke D.A., Da Silva P., Aitken R.P., 2001. Nutrient partitioning during adolescent pregnancy. Reproduction 122, 347-357

Wallace J.M., Da Silva P., Aitken R.P., Cheyne M.A., 1997. Maternal endocrine status in relation to pregnancy outcome in rapidly growing adolescent sheep. J. Endocrinol. 155, 359-368

Wallace J.M., Milne J.S., Aitken R.P., 2004. Maternal growth hormone treatment from Day 35 to 80 of gestation alters nutrient partitioning in favour of uteroplacental growth in the overnourished adolescent sheep. Biol. Reprod. 10.1095/biolreprod.103.023853 